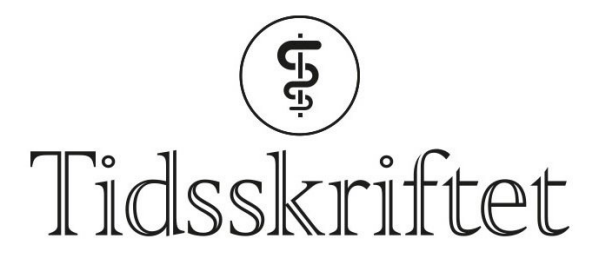

DEN NORSKE LEGEFORENING

\title{
Kan tarmfloraen føreseie effekt av behandling?
}

FRA ANDRE TIDSSKRIFTER

KRISTINE LILLESTØL

Universitetet i Oslo

Respons på diettbehandling ved irritabel tarm-syndrom kan vere knytt til pasientens tarmbakterieprofil.

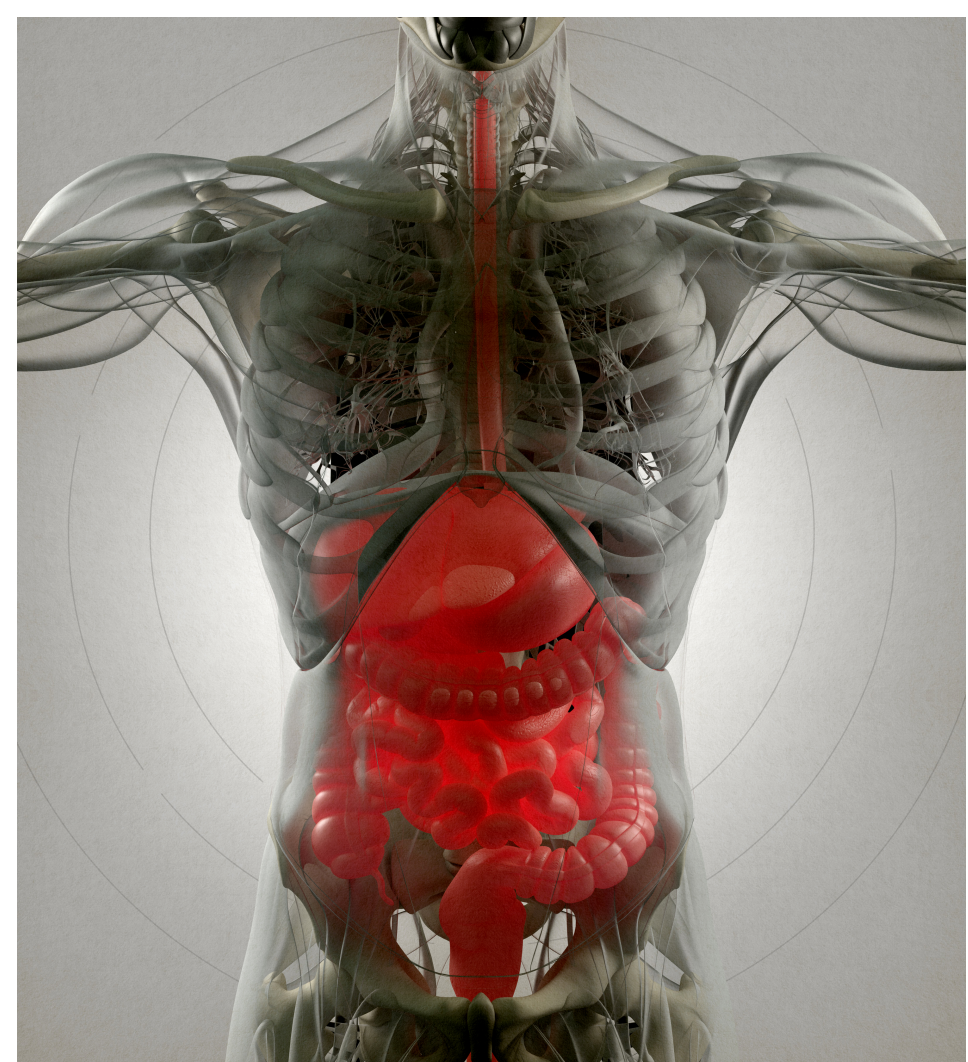

Illustrasjonsfoto: ChrisChrisW/iStock

Behandling av irritabel tarm-syndrom (IBS) er utfordrande. Diett lettar plagene for somme, men det gjeld langt frå alle, og det er førebels vanskeleg å seie på førehand kven som responderer på slik intervensjon.

I ein ny studie er samanhengen mellom fekal bakterieprofil og respons på diettbehandling ved irritabel tarm-syndrom undersøkt (1). Studien byggjer på sekundæranalysar av 61 pasientar frå ein intervensjonsstudie. Pasientane vart randomisert til å følgje anten ein såkalla tradisjonell IBS-diett, eller ein diett med lågt inntak av FODMAP (fermenterbare 
oligosakkarid, disakkarid, monosakkarid og polyolar). Det vart samla avføringsprøver til analyse av bakterieprofilar. I gruppa som fekk låg-FODMAP-diett, var det fleire skilnader i fekal bakterieprofil mellom dei som responderte på behandling og dei som ikkje gjorde det, både før og etter intervensjonen. Slike skilnader var det ikkje i gruppa som fekk tradisjonell IBS-diett.

- At tarmfloraen kan påverke behandlingsresponsen ved irritabel tarm-syndrom er ein besnærande tanke, seier Jørgen Valeur, leiar ved Unger-Vetlesens Institutt ved Lovisenberg Diakonale Sykehus. - Denne studien var imidlertid ikkje primært designa for å undersøke dette, seier han.

- Tidlegare studiar har langt på veg avkrefta eksistensen av ein veldefinert «mikrobiell signatur» ved irritabel tarm-syndrom. Det er likevel spennande at visse tarmfloramarkørar kanskje kan brukast til å føreseie korleis det vil gå med pasienten. Omgrepet «persontilpassa medisin» må sannsynlegvis supplerast med «tarmfloratilpassa medisin» i nær framtid, seier Valeur.

\section{LITTERATUR:}

1. Bennet SMP, Böhn L, Störsrud S et al. Multivariate modelling of faecal bacterial profiles of patients with IBS predicts responsiveness to a diet low in FODMAPs. Gut 2017; gutjnl-2016-313128.E-publisert 17.4.2017. [PubMed][CrossRef]

Publisert: 17. april 2018. Tidsskr Nor Legeforen. DOI: 10.4045/tidsskr.18.0137

(C) Tidsskrift for Den norske legeforening 2020. Lastet ned fra tidsskriftet.no 